\title{
ASSESSMENT OF ANTHROPOGENIC ECOLOGICAL SYSTEMS IN THE APOLD DEPRESSION TO A SUSTAINABLE MANAGEMENT
}

\author{
Ecaterina, LENGYEL ${ }^{1}$, Diana Ionela, STEGĂRUȘ ${ }^{2}$, Corina Teodora, CIUCURE ${ }^{2}$, Ovidiu TIȚA ${ }^{1}$ \\ 1’Lucian Blaga" University of Sibiu, Romania, e-mail: ecaterina.lengyel@ulbsibiu.ro \\ ${ }^{2}$ National Institute for Research and Development for Cryogenics and Isotopic Technologies - ICIT Rm. Valcea, Ramnicu Valcea, \\ Romania
}

\begin{abstract}
The Apold Depression and especially the locality of Apoldu de Jos are mentioned in historical writings from the earliest times. It was mentioned in official documents as early as 1288 by the king of Hungary, Ladislaus IV the Cuman (12721290). A community of free people, they harnessed their natural resources in such a way that they still have a good reputation. Sustainable management of this area is very important for viticulture and agriculture.

Due to its geographical position, the Apold Depression was always a favorable place for the cultivation of grapevine. The crops recorded the mark of a redox environment which favors the accumulation of free and bonded aromas in grapes. The research studies have shown that these aromas are clearly influenced by the geological structure of the area, soil composition, climate, exposure, slope, abundance of precipitations. All these give typicality to the wines of a vineyard (goût de terroir).
\end{abstract}

KEYWORDS: Apold Depression, sustainable management, slope exposure, climate factors

\section{INTRODUCTION}

This study goal is the scientific substantiation for the sustainable management of some ecological systems categories under anthropogenic impact, based on the characteristic structures and procesess.

The wines from the vineyard Sebes-Apold, bears the mark of the micro climate and grape ripening conditions, varieties are appreciated for freshness, fruitiness, finesse. Aromatic palette is typical and specific of the variety and climatic conditions, the wines are characterized by a high acidity that gives freshness, vivacity, balance and harmony. Vegetable flavors, floral and slightly higher acidity prints notes characteristic wines, own vineyard.

The Apold Depression lies north of the Cindrel Mountains, in the South-West of the Transylvanian Plateau, stretching over $265.27 \mathrm{~km}^{2}$. It is bordered by the Secașe Plateau in the North and the Amnaş Plateau in the North-East. It is hilly; the average altitude is $450 \mathrm{~m}$, while the maximum altitude is 574 $\mathrm{m}$. It is this position that led to the configuration of hydrographic and climatic particularities favorable to grapevine cultivation. Thus, a climatic calmness is ascertained, alternating Western (oceanic) influences, and influences from the Cindrel and the Apuseni Mountains (foehn), as well as thermic inversions in the colder period of the year [TeuşanPleșia, 2011].

In Apold depression is felt a rich network of water as Secasul Mare and its tributaries coming from Cindrelului Mountains and his foothills Cindrelului and Secaşelor Plateau.
Secaşul Mare is a right tributary of the Sebeş River downstream from the locality of Lancrăm; thus, it becomes a hydrographical component of the Western Group.

\section{RESULTS AND DISCUSSION}

\subsection{Relief from the Apold Depression}

The Apold Depression reaches altitudes between $230 \mathrm{~m}$ and 574 and is considered a submontane depression. The slopes in the Apold Depression are grouped under six categories. Slopes below $5^{\circ}$ are observed on the plains and terraces of the Secaşul Mare River and its left tributaries; these are stable areas [Fărcașiu, 2008, Grecu, 1992]. These slopes cover about 136.8 $\mathrm{km}^{2}$. The next category of slopes $\left(5-10^{\circ}\right)$ can be found in the lower part of the versants and cover about $106.7 \mathrm{~km}^{2}$. The slopes over $10^{\circ}$ encountered in this area are less important, in this category the vertical versants of the Reciu, Gârbova, Câlnic and Dobârca valleys are observed [Cocean et al.,2009, Grecu et al., 2003].

\subsection{Slope exposure}

The slopes mainly present a Northern (38.2\%) and Eastern (29.4\%) exposure. Southern exposure $(13.5 \%)$ is favorable to viticulture. This percentage is rather low if we take into account the fact that slopes directly influence vegetation and the possibility to use lands, which are important factors for people's interest. Only about $18.9 \%$ of the lands in the Apold Depression are exposed to the West (Figure 1). 


\section{Exposure Apold depression}

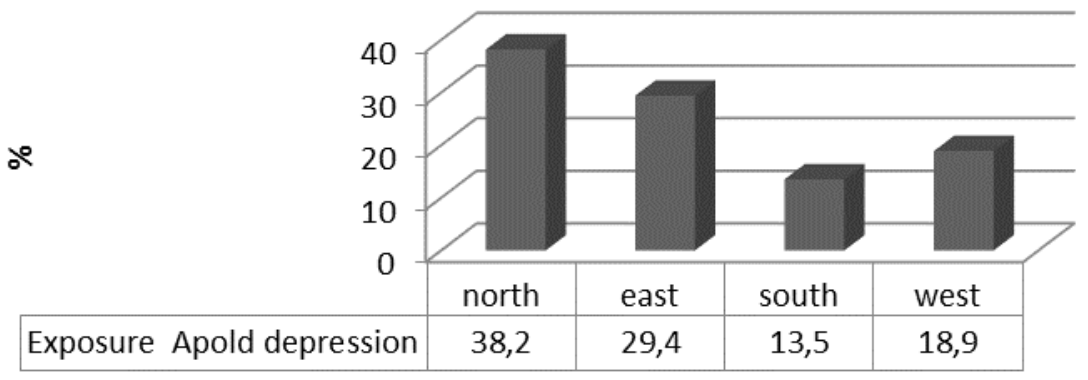

Figure 7. Slope exposure in the Apold Depression (\%)

\subsection{Climate factors}

Climate plays an important part in the formation of typical soil traits. We can mention precipitations, air circulation, temperatures in 2004-2013. The Apold Depression is characterized by unstable and cool summers and longer, milder autums with higher relative humidity [Georgescu, 2002; Costea, 2005]. This leads to favorable ripening conditions and optimal aging conditions for grapes. Bumper crops are stable.

\section{Precipitations}

The precipitation level is between 400 and $700 \mathrm{~mm} / \mathrm{year}$. This leads to optimal vine growth, with a minimum of $250 \mathrm{~mm} / \mathrm{year}$ in the growth cycle.
According to figure 2, between 2009 and 2013, the precipitation levels measured in the Apold Depression range between 595 and $635 \mathrm{~mm} /$ year.

Precipitations play a decisive part in the qualitative development of grapes, but they are not beneficial, especially in summer. In the growth cycle, it is best that relative precipitation levels are below $350 \mathrm{~mm}$. Then, the crop is considered good if the precipitation level decreases in the ripening cycle. Droughty summers favor the accumulation of sugars in grapes. In figure 3 is presented the annual rainfall measured during the growth cycle and as it can be observed, in most years, the rainfall recorded optimal values between 300 and $330 \mathrm{~mm}$.

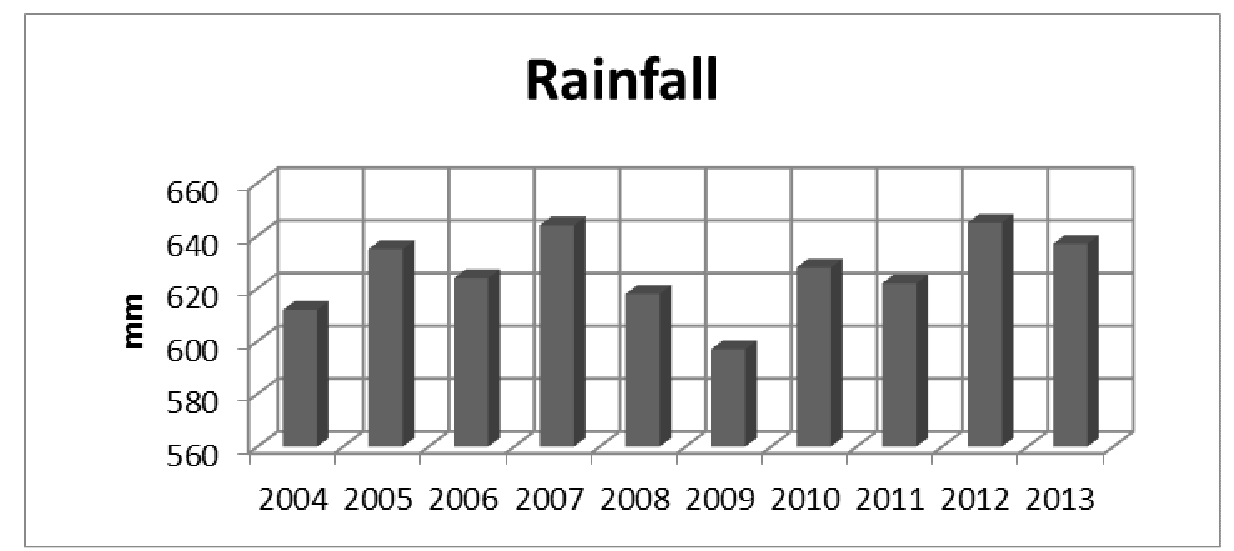

Figure 8. The amount of rainfall measured in a 10-year interval in the Apold Depression

In 2004, precipitation levels reached $300 \mathrm{~mm}$, and the following year they recorded a minor decrease of $5 \mathrm{~mm}$. In 2006, the precipitation level increased to $327 \mathrm{~mm}$, while the following year they increased by $3 \mathrm{~mm}$. In 2008, the precipitation level was $318 \mathrm{~mm}$, while the following year it dropped to $295 \mathrm{~mm}$. In 2010, precipitation levels increased to $325 \mathrm{~mm}$, while the following year precipitation levels decreased by $5 \mathrm{~mm}$. In 2012, we notice an increase of precipitations to an average of $335 \mathrm{~mm}$. In 2013, precipitation levels were $5 \mathrm{~mm}$ lower. Figure 3 shows that the years 2005 and 2009 were drier, with a reduced precipitation level. The following years recorded high precipitation levels: 2007, 2012, and 2013.

\section{Annual rainfall measured during the growth cycle}

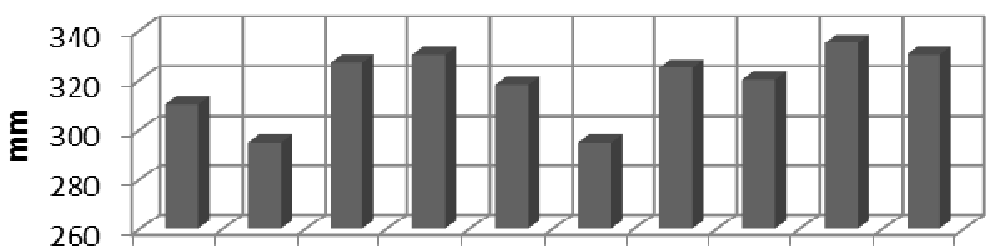

2004200520062007200820092010201120122013 
Figure 9. Annual rainfall measured during the growth cycle in a 10-year interval in the Apold Depression

If we characterize the quality of the grape crop from the Apold Depression in the interval when the measurements were taken, we ascertain that the lowest relative precipitation levels in the growth cycle were recorded in 2005 and 2009: $295 \mathrm{~mm} .2012$ was the year with the highest precipitation levels: $335 \mathrm{~mm}$. The years 2005 and 2009 were the most favorable for grape crops, recording the lowest values, i.e. $295 \mathrm{~mm}$. 2012 recorded a value of $335 \mathrm{~mm}$, being the year when the grapes had the lowest sugar content, because of relative precipitation levels.

Relative humidity is an indicator of grape quality (Figure 4). Grapes develop harmoniously if conditions oscillate between $70-80 \%$.

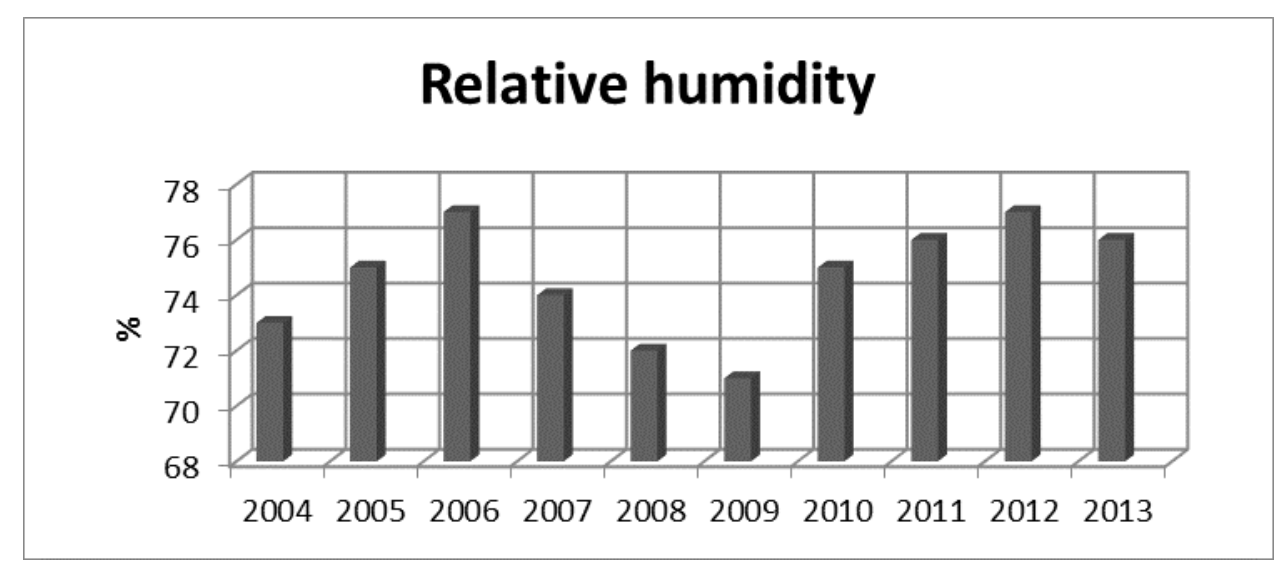

Figure 10. Relative humidity measured in a 10-year interval in the Apold Depression

In 2004 , relative humidity was at $73 \%$; the following year the value recorded was $75 \%$, equal to that of 2010 . In 2006 , humidity levels reach $77 \%$, equal to those of 2012. In 2007 , relative humidity reaches $74 \%$. The year 2008 presents $72 \%$ relative humidity, while in the year 2009 it reaches $71 \%$. In 2011 and 2013, relative humidity reaches $76 \%$.

These measurements show that 2009 records the lowest level of relative humidity (71\%), and that, 6 years apart, the years 2006 and 2012 record the highest value: $77 \%$.

It is ascertained that, during all these 10 years, relative humidity does not surpass the threshold of $77 \%$, nor does it drop under $71 \%$. Under these conditions, grapes develop harmoniously.

The average annual temperature is the sum of thermal values measured in a 1-year interval and divided by the number of days (Figure 5).

The year 2010 was the coolest, with an average annual temperature of $9.25^{\circ} \mathrm{C}$, while the year 2011 was the warmest, with an average temperature of $9.37^{\circ} \mathrm{C}$. In the last 10 years, the average annual temperature varied between $9.25^{\circ} \mathrm{C}$ and $9.37^{\circ} \mathrm{C}$. The year 2011 is noticeable, as temperatures increased by $0.12^{\circ} \mathrm{C}$, in contrast with $9.25^{\circ} \mathrm{C}$ recorded in 2010 .

\section{The average annual temperature}

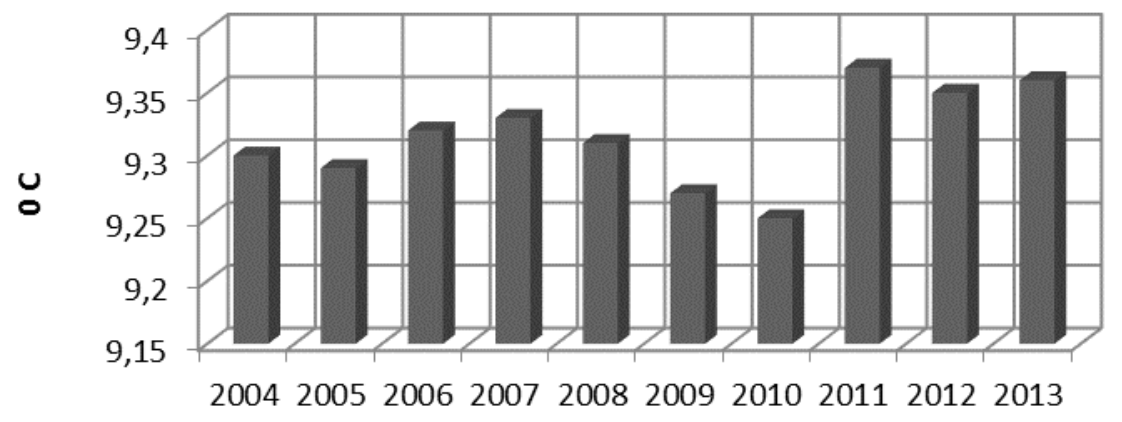

Figure 11. The average annual temperature measured in a 10-year interval in the Apold Depression

In the years 2011 and 2013, there is a slight difference between the average annual temperature, i.e. $0.1^{\circ} \mathrm{C}$; the temperature recorded in these years is close to that recorded in 2012 $\left(9.33^{\circ} \mathrm{C}\right)$;

In 2009, an important decrease in temperature was recorded: the temperature dropped by $0.6^{\circ} \mathrm{C}$ from $9.31^{\circ} \mathrm{C}$, recorded in 2008 , to $9.25^{\circ} \mathrm{C}$ in 2007 . The average annual temperature in the 10 -year interval is $9.31^{\circ} \mathrm{C}$;

The average temperature in the growth cycle is the sum of temperatures measured daily in spring $\left(\mathrm{T}>10^{\circ} \mathrm{C}\right)$ and autumn until the first frost $\left(\mathrm{T} \leq-2^{\circ} \mathrm{C}\right)$, divided by the number of days. In the Apold Depression, the average growth cycle is 178 days (fig. 6).

As we can see, the average temperature in the growth cycle, measured in the years 2004, 2006, 2007, 2008 and 2011 respectively, is constant, reaching $17.3^{\circ} \mathrm{C}$. In the years 2005 , 2009 and 2010, a slight decrease is noticed; the average temperature is $17.2^{\circ} \mathrm{C}$. The highest average temperature can be noticed in the last 2 years, 2012 and 2013, with values reaching $18.3^{\circ} \mathrm{C}$. In this case, the temperature increases by more than $1^{\circ} \mathrm{C}$. 


\section{The average temperature in the growth cycle}

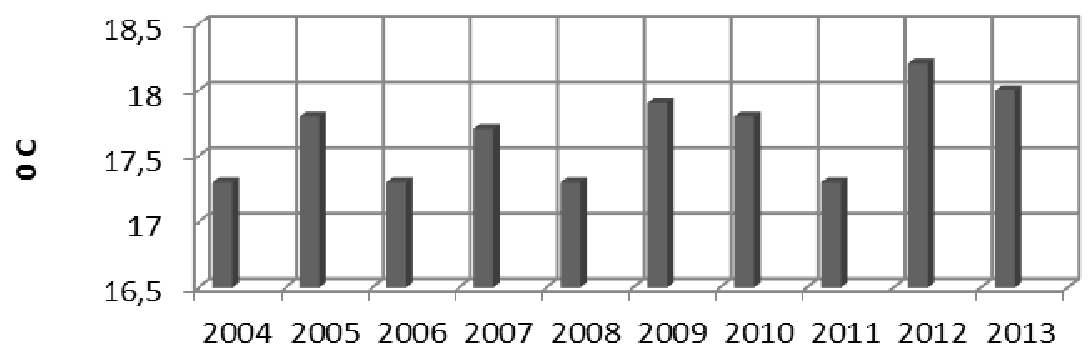

Figure 12. The average temperature in the growth cycle measured in a 10-year interval in the Apold Depression

The average temperature in the aging period is calculated for the interval September $20^{\text {th }}$ and October 10th and is an average of the temperatures recorded in this time (Figure 7).

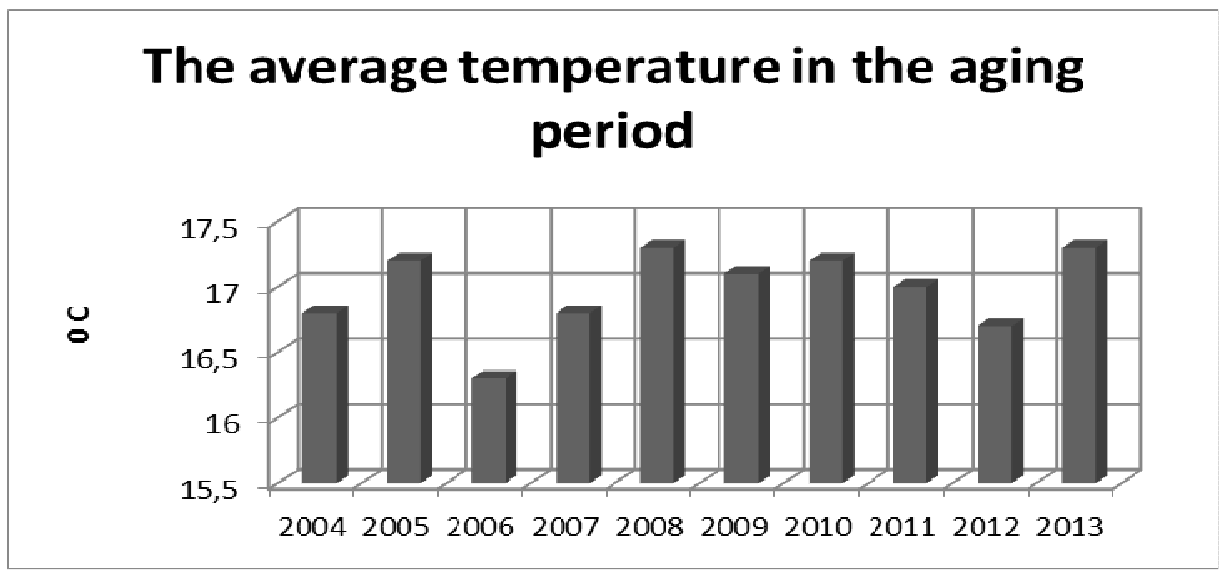

Figure 13. The average temperature in the aging period measured in a 10-year interval in the Apold Depression

In 2006 , the average temperature reached $16.3^{\circ} \mathrm{C}$ and was the lowest temperature measured in the aging period.

In 2008 and 2013, the same temperature was recorded $\left(17.3^{\circ} \mathrm{C}\right)$, being the highest aging temperature. The temperature doesn't influence the aging period, because the differences recorded along this years were insignificant.

As in the case above, in 2005 and 2010, the same temperature of $17.2^{\circ} \mathrm{C}$ was recorded.

A similar case is that of the years 2004 and 2007, when the average temperature recorded in the aging period was $16.8^{\circ} \mathrm{C}$.
The aging temperature varied in the years: 2009, when the aging temperature reached $17.1^{\circ} \mathrm{C}$; 2011 , when the aging temperature reached $17.0^{\circ} \mathrm{C}$; 2012, when the aging temperature reached $16.7^{\circ} \mathrm{C}$;

The oenoclimatic aptitude index is the sum of the active heat balance and the real hours of sunshine, from which we substract the excess precipitations during the active life of vines. 


\section{The oenoclimatic aptitude index}

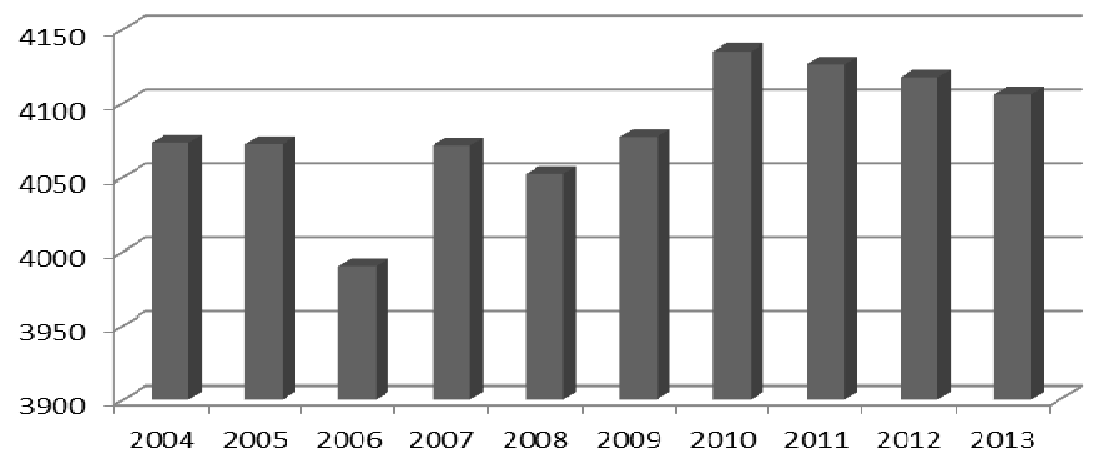

Figure 14. The oenoclimatic aptitude index calculated in a 10-year interval in the Apold Depression

The study conducted during a 10-year interval in the Apold Depression, aiming at determining the oenoclimatic aptitude index, showed that the values recorded are specific to the cool climate in the Southern part of the Transylvanian Plateau, (Figure 8) as follows:

The year 2004, the first monitored in the study, recorded an oenoclimatic aptitude index value of 4073 . The following year, the aptitude index slightly decreased, reaching 4072 value 2006, the third year studied, was the year when the lowest index value was recorded: 3990 . Nevertheless, this value falls within the threshold specific to the area. The year 2007 once again brought higher, but fluctuating values, as follows: in 2007 - the value recorded reached 4071; 2008 recorded a slight decrease: 4052; 2009 recorded a yet again increasing value: 4077.

The 7th year studied, 2010, recorded the climax value, i.e. the highest index value in the studied years: 4135 . The following 3 years recorded another, slighter decrease: in 2011 - the value recorded was 4126; in 2012 - 4117 and, in 2013, the last year studied, the value recorded was 4106 .

Therefore, we can conclude that, at first, we recorded decreasing values of the oenoclimatic aptitude index. In 2006, we recorded the minimum value in the study, followed by a period in which we recorded fluctuating values, until 2010, when the global average temperature was the highest, thus the maximum value recorded in the study; the period was once again followed by a progressive decrease in values.

As the years pass by, it is ascertained that the index value decreases by one unit per year, from 4073 to 4072 .

\section{CONCLUSION}

We can conclude that, taking into consideration the studied indices - the Apold Depression allows for the harmonious development of grapevine crops and that fact that the native varieties gather aromas from all the factors presented above. The sustainable management of the Apold depression is vital to retain its oenological and agricultural ecosystem in the region.

In addition, it can be said that indices monitored in the depressionary area Apold allow the harmonious development of vine cultures so the indigenous varieties which reached maturity can accumulate flavors from all these factors outlined above.

The most favorable years of wine cultures from point of the rainfall were 2005 and 2009, because were registered the lowest values $(295 \mathrm{~mm})$, which favored the development of aroma compounds.

The average temperature during the vegetation period varies between $17.2^{\circ} \mathrm{C}$ and $18.3^{\circ} \mathrm{C}$ which leads to grape production normally. From literature, oenoclimatic aptitude index was concluded that in 2006 distinguished the minimum value of study in contrast with 2010 which was the highest touching average global temperature, allowing the harmonious development of vine culture easily incorporating of flavor compounds.

\section{ACKNOWLEDGMENT:}

This work was supported by the strategic grant POSDRU/159/1.5/S/133255, Project ID 133255 (2014), cofinanced by the European Social Fund within the Sectorial Operational Program Human Resources Development 20072013

\section{REFERENCES}

59. Cocean Pompei, Deszi Ştefan, Geografia turismului, Edit. Presa Universitară Clujeană, Cluj-Napoca, Romania, (2009).

60. Costea Marioara, Bazinul Sebeşului. Studiu de peisaj, Edit. Univ. „Lucian Blaga”, Sibiu, Romania, (2005).

61. Fărcaşiu Vasile, Apoldul de Jos. Veche vatră românească de istorie şi cultură. Culegere de lucrări monografice, Edit. Univ. „Lucian Blaga”, Sibiu, Romania, (2008).

62. Georgescu Niculaie, Centrul viticol Apold-Sibiu: vocaţie şi potenţial de producţie, Alma Mater, Sibiu, Romania, (2002).

63. Grecu Florina, Bazinul Hârtibaciului. Elemente de morfohidrografie, Edit. Academiei Române, Bucureşti, Romania, (1992).

64. Grecu Florina, Palmentola Giovanni, Geomorfologie dinamică, Edit. Tehnică, Bucureşti, Romania, (2003).

65. Teușan-Pleșia Damaris, Dinamica spațiului geographic in Depresiunea Apoldului, Edit. Univ. „Lucian Blaga”, Sibiu, Romania, (2011). 